\title{
Digitalizáció és sport: az IKT kihívásai a testnevelő képzésben
}

\author{
Antal Péter \\ Eszterházy Károly Egyetem, Médiainformatika Tanszék \\ antal.peter@uni-eszterhazy.hu
}

\section{Digitalization and Sports: ICT-related challenges in Physical Education teacher training}

The principal challenge of the 21st century is the digitalization process requiring the educational sphere to meet the demands of the new instructional environments. While digital devices have been virtually fully integrated in the instruction of natural science or humanities subjects, different expectations apply to Physical Education teachers as digital boards do not play a significant role in such instruction programs. At the same time the increasing prevalence of digitaland communication technology both in competitive and recreational or amateur sports calls for the instruction of new competences in Physical Education training programs.

Suffice to mention portable analytical devices assessing and analyzing the actual state and the changes of athletes' physiological conditions in real time and in real contexts. Furthermore, tactical analysis, efficiency surveillance, or movement analysis programs along with devices monitoring performance and physiological conditions pervading non-professional sport as well can provide crucial help to athletes and coaches. Since students enrolled in Physical Education teacher training programs are expected to have different ICT skills from their other colleagues in the profession special training schemes are required for them.

My presentation at the juncture of sports and ICT introduces the information technology aspects of the Physical Education teacher training programs at Eszterházy Károly University and compares the results of a survey performed among Physical Education teachers with that of the international trends.

Keywords: ICT, Digitalization, Sport, Performance, Competences.

\section{Bevezetés}

A 21. század a digitalizációról szól, melynek fontos kihívása, hogy az oktatás is megfeleljen az új oktatási környezetnek. Mig a természettudományos vagy humán tantárgyak esetében egyre természetesebb a digitális eszközök használata addig a testnevelés tárgy oktatásában teljesen mások az elvárások, hiszen a digitális tábla, mint eszköz, nem játszik fontos szerepet egy testnevelő repertoárjában. Ezzel szemben a digitális- és kommunikációtechnológia hihetetlen mértékben beszivárgott a verseny- és amatör sportba egyaránt és új kompetenciák igényét generálja a testnevelök felkészitésében.

Gondoljunk csak azokra a hordozható analitikai eszközökre, amelyek, a sportolók fiziológiai állapotának, változásait valós idöben, valós körülmények között képesek mérni és analizálni. Ugyanilyen fontosak a taktikai elemzéseket végzö, 
hatékonyságot figyelő, vagy mozgáselemző programok, vagy amatőr sportban is használt teljesítményt és fiziológiai állapotot monitorhozó eszközök, amelyek segithetik a sportolókés edzők munkáját. Éppen ezért fontos a testnevelő képzésben résztvevő hallgatók, speciális felkészitése, hiszen teljesen más IKT eszközökkel kerülnek szembe, mint a közoktatás egyéb szereplői.

Előadásomban a testnevelő szakos hallgatók információtechnológiai felkészitését és képzési rendszerét mutatom be, az Eszterházy Károly Egyetemen, illetve egy testnevelök körében végzett felmérés eredményeit hasonlítom össze a nemzetközi trendekkel a sport és IKT témakörében.

\section{A globális sporttechnológiai piac alakulása a napjainkban}

A Transparency Market Research által közzétett új piaci jelentés szerint 2016-ban [6] a globális sporttechnológiai piacot 21.609 millió dollárra értékelték. Ez az érték a becslések szerint, 2019 és 2027 között 14,7\% -os éves növekedési rátával számolva, eléri a 93.825 millió dollárt 2027-re. Ez elsősorban a technológiai fejlesztésektöl és a sporttechnológiai háttér informatikai támogatásának a növekedésétöl függött, föleg a kiemelt sportok körében.

A legkeresettebbek, az analitikai megoldások, a hordozható eszközök, a csapatmenedzsmentettámogatóalkalmazások,azegyénisportolóiteljesitményeket és a csapatteljesitmény adatait feldolgozó szoftverek és szolgáltatások.

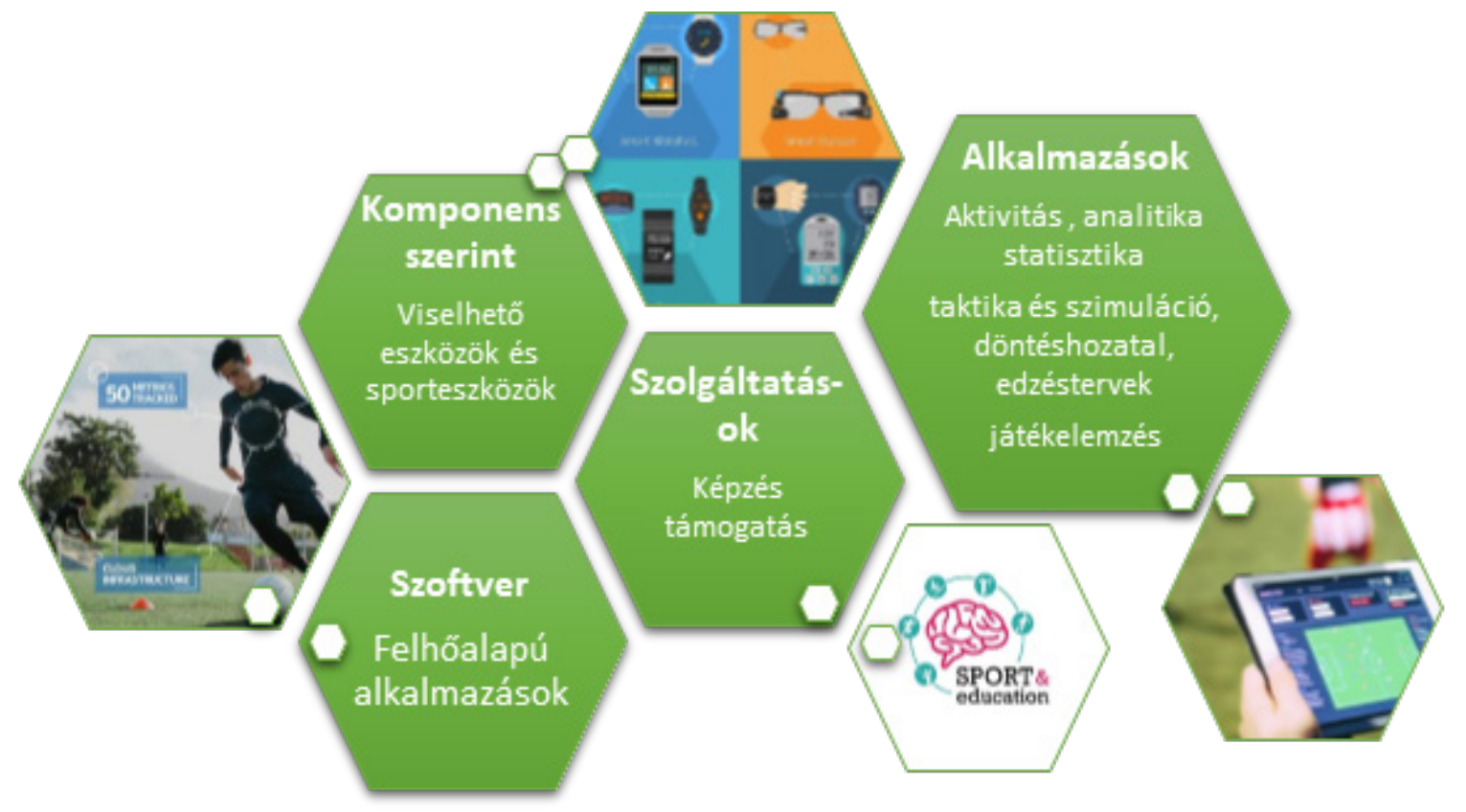

1. ábra: A sporttechnológiai piac összetevöi 
A sporttechnológiai piac összetevőit többféle szempontból elemezhetjük.

- Komponens szerint

- Viselhető eszközök és sporteszközök

- Szoftver

- Felhöalapú alkalmazások

- A helyszini adatfelvétel

- Szolgáltatások

- Képzés és megvalósítás

- Támogatás és karbantartás

- Irányitott / kiszervezett szolgáltatások

- Alkalmazás szerint

- Aktívitás követés

- Analitika és statisztika

- Taktika és szimuláció

- Döntéshozatali támogatás

- Edzéstervek

- Játék teljesitmény elemzése

- Csapatelemzés és -kezelés

- Sérülés és egészségügyi elemzés

A fent látható portfólióból kiderül, hogy a sport és a technológia összefonódása egyre intenzivebb folyamat lesz, gyakorlatilag a jövö egyik leghasznosabb teljesitménynövelő eszközévé maga a technológia válik.

Ezen belül a viselhetö eszközök jelentik majd a legnagyobb piacot, hiszen ezek közvetlenül tudnak majd adatokat szolgáltatni az elemzöknek. Az Ericsson cég 2016-os kutatásai szerint [5], 2020-után éri el a technológia azt a szintet, hogy komoly orvosi diagnosztikára is alkalmasak lesznek, akár a mobiltelefonokat is helyettesiteni tudják. Megjelenik a viselhető eszközök internete, ami segit a felhasználóknak interakcióba kerülni más fizikai tárgyakkal, ami nem feltétlenül eszközöket jelent. A felhasználók 60 százaléka gondolja úgy, hogy a következö öt év során a tabletták és a bör alá ültetett chipek el fognak terjedni - és ezek nemcsak az egészségügyi adatok nyomon követésére lesznek használhatók, hanem ajtók nyitásához, tranzakciók és személyazonosság hitelesitéséhez, és tárgyak vezérléséhez. Már ma is az okostelefon-használók 25 százaléka használja az okostelefonját arra, hogy távolról vezéreljen digitális eszközöket otthonában, és 30 százalékuk használ hangalapú keresést az okosóráján. 


\section{VISELHETŐ JÖVŐ}
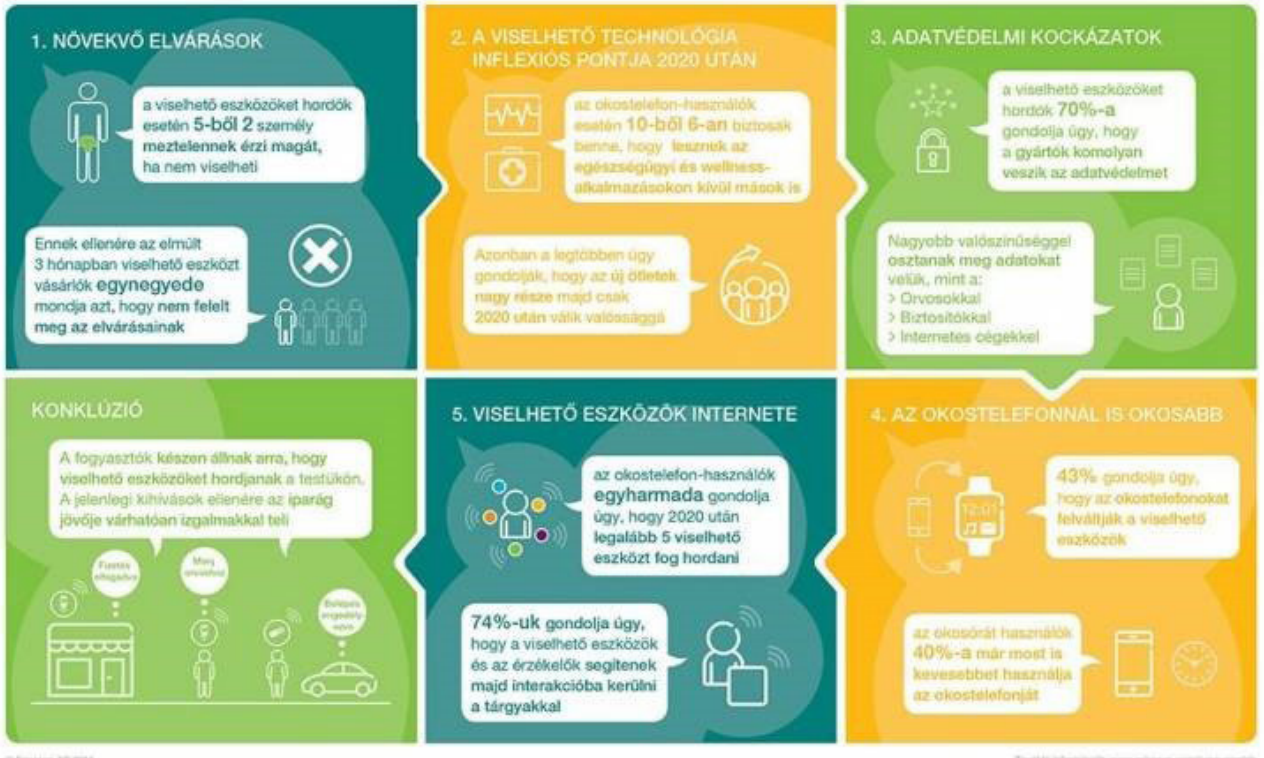

2. ábra: A viselhetö jövö trendjei [5]

\section{A technológia szerepe a testnevelés oktatásában}

Atechnológiajelenlététés szükségességétasportban ma márnem kérdőjelezhetjük meg és a bevezető részböl is kiderül, hogy a profi sport már kihasználja ezeket a lehetöségeket. A testnevelö képzésben viszont komoly elmaradások vannak a viselhető eszközök iskolai alkalmazásának módszertanában [3].

Még Európában is ritkák azok a kezdeményezések, ahola közoktatásban használnák ki a viselhető eszközök lehetöségeit. Egyik ilyen példa a spanyolországi BarcelonaPárizs virtuális futás tapasztalatai [2], Illetve hasonló még az olaszországi "The Portable Devices as Means to Promote Children's Active" kisérlet, amely a gyerekek iskoláig történő gyaloglását próbálta meg segiteni és inspirálni mobil alkalmazás segitségével. [1]

Magyarországon az utóbbi években kiemelt szerepet kapott az iskolai tevékenységekben a testmozgás, hiszen a 2011/12-es tanévtöl, heti 5 órában, kötelező a mindennapos testnevelés a hazai közoktatási intézményekben, melynek eredményessége fontos a felnövekvő nemzedékek szempontjából. A Magyar Diáksport Szövetség 2013-ban inditotta útnak a "A testnevelés új stratégiájának és a fizikai állapot új mérési rendszerének kialakitása és az önkéntes részvétel ösztönzése a komplex iskolai testmozgásprogramok szervezésében" -T.E.S.I. elnevezésü kiemelt projektjét. 
A projekt célja volt, hogy létrehozza a magyar iskolarendszerben egységesen müködtethető, egészségközpontú fittségmérési-értékelési rendszert, a NETFIT-et. A NETFIT szoftveres alkalmazása olyan személyre szabott értékelési lehetőséget kinál minden tanuló számára, amely vizuálisan is szemlélteti a fittségi állapotot, valamint konkrét ajánlásokat fogalmaz meg a fejlesztés érdekében. A NETFIT rendszert közel 3700 iskola, 800 ezer tanuló és 13 ezer pedagógus használja. A rendszer hatékony használatához elengedhetetlen a testnevelök részéröl a nyitottság a digitális kompetenciák megszerzésére. A testnevelő képzésben viszont nem történik meg a felkészités a rendszer használatára [4].

\section{IKT innováció a testnevelö képzésben}

A fenti trendekből jól látszik, hogy egy nagyon dinamikusan fejlődő informatikai szegmenssel van dolgunk, amit a képzési struktúra sem hagyhat figyelmen kivül.

Az Eszterházy Károly Egyetemen korábban is volt a testnevelök részére a technológiát oktató kurzus, Oktatás- és kommunikációtechnológia néven, de ez elsösorban a tanári pályán általánosan elöforduló IKT eszközök használatára és módszertani lehetőségeire korlátozódott.

A 2017/18-as tanévtöl azonban kisérleti jelleggel elinditottunk egy speciális kurzust új tartalommal a testnevelök részére IKT innovációk néven.

A kurzus célja, hogy megismertesse a hallgatókat a 21. század IKT eszközeinek hatékony alkalmazásához szükséges ismeretekkel, különös tekintettel azok sport és rekreációs tevékenységek során történő alkalmazására. Fontos az új sporttechnológiák és módszerek megismertetése a hallgatókkal, illetve ezek alkalmazási módszertanának kidolgozása a szakiránynak megfelelően.

A kurzus két kredit értékü, heti két órás gyakorlatot takar egy féléven keresztül.

A legfontosabb témakörök a következök:

- Az információs és kommunikációs technológiák (IKT) hatása a 21. században

- Az IKT fogalomrendszere, az információs- és hálózattársadalom alapjai

- A21. század kommunikációs és oktatási formái: az elektronikus tanulási környezet fogalomrendszere.

- A technológiák alkalmazási lehetőségei az amatör és versenysportban (sportanalitikai, teljesítményelemző rendszerek)

- Viselhető technológiák, kreatív médiatechnológiák (okoseszközök használata a sport és a rekreációs tevékenységek során.

- Az iskolai alkalmazás eszközei és szoftverei, adatmegosztás a felhöben

- A hordozható eszközökre épülö ismeretelsajátítás, mobil kommunikációs eszközök és a tartalomipar, és az iskolai teljesitménymérés lehetőségei

- Személtetés, szemléletesség. Az elektronikus publikáció sajátosságai, a prezentálás alapjai.

- On-line prezentációkészités- Prezi a gyakorlatban

- A digitális technológiára épülő kutatástervezés alapjai. 


\section{A tantárgy relevanciájának vizsgálata}

A tantárgy tartalmi relevanciájánakés a hallgatói vélemények mérésénekérdekében egy kérdöíves felmérést és mini interjúk készitését végeztem el a nappalis és levelező hallgatók körében, összesen 38 fö válaszolt.

Akérdőiveskérdésekahallgatóktechnológiaitájékozottságára, azeszközhasználatra, illetve a tantárgyi relevanciára vonatkoztak.

A miniinterjúk során elsösorban arra a kérdésre voltam kiváncsi milyen ismeretekkel rendelkeznek azok a hallgatók, az információs társadalomról és annak hatásairól, akik a koruk alapján már a digitális bennszülöttek táborába tartoznak.

A beszélgetés témakörei a következők voltak:

1. Ön szerint milyen hatással van a technológiai fejlődés a korosztálya életére (proés kontra).

2. Hogyan képzeli el a modern technológiák felhasználását a saját sportágában?

3. Milyen hatással van média a sportra, és a sport a médiára, milyen elönyök, hátrányok származnak ebből?

4. Hogyan képzelik el a jövö IKT eszközeit? Mit gondol milyen új eszközök fognak megjelenni?

5. Hogyan segitheti a sportot a technológia, milyen eszközöket látnának szivesen, illetve hogyan tudnának ezek segiteni a sportban?

6. Hogyan itélik meg, hogy általános- és középiskolában illetve a felsőoktatásban felkészitették-e Önöket az információs társadalom kihivásaira és megfelelő szintünek tartják-e ezt?

Jelen cikkben csak a legérdekesebb kérdéseket elemzem a következőkben.

\section{A kérdöiv eredményei}

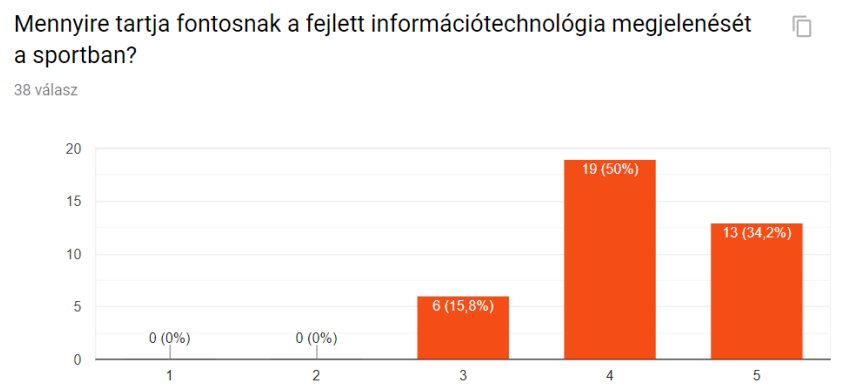

A kérdésre mindenki pozitiv választ adott, gyakorlatilag a hallgatók $80 \%$-a érzékeli a modern technológiában rejlő lehetőségeket, hogy segitséget nyújthat a sportban. Amint az eredményböl látszik, még mindig van 20\% akik elutasitják a technológiai vivmányok használatát a sportban. Ennek oka többféle lehet, az elutasitók többsége olyan eszközökre gondolt, amelyek illegálisan segitik a sportolókeredményességét, illetve nem élsportolók és nem látták bizonyitottnak a technológia szükségességét a sportágukban. 
Használ(t) -e valamilyen okos eszközt sporttevékenység közben? 38 válasz

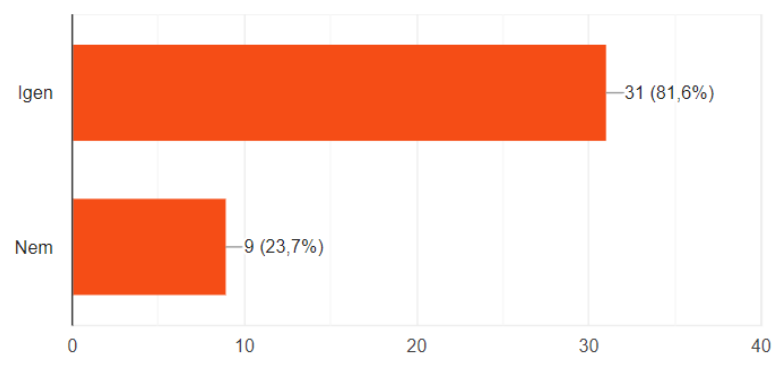

Az eszközhasználattal kapcsolatban is pozitiv a hallgatók véleménye, sokan használtak vagy használnak viselhető eszközöket. Legtöbbjük okosórát, testszenzort használt már telefonnal tablettel kombinálva. Speciálisabb eszközöket (okosruha, okoscipő, kardiológiai adatokat mérö) eszközöket azonban nem. Az is kiderült, hogy nem mindenki alkalmazza őket megfelelően, illetve nem használja ki ezek lehetőségeit maximálisan, ami elsősorban abból adódik, hogy nem is ismerik megfelelően az eszközöket.

Milyen motiváló erővel hathat a technológia használata a sportban?

38 válasz

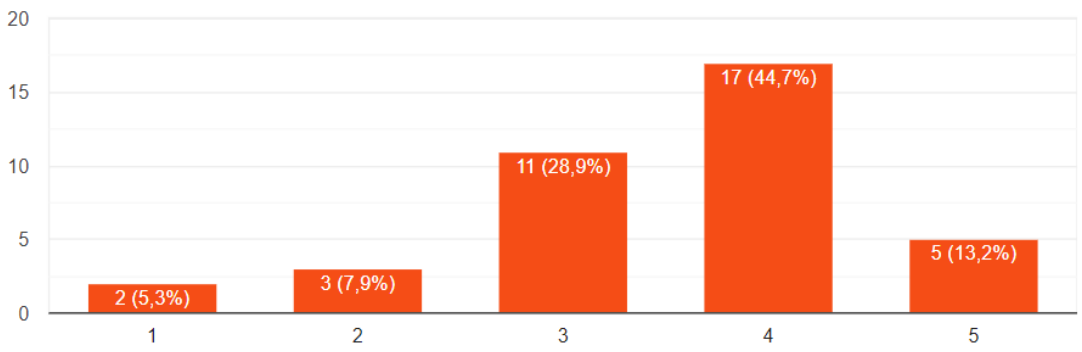

Arra a kérdésre, hogy van e motivációs ereje a viselhetö eszközöknek a sportban zömében pozitivan válaszoltak, elsősorban a gyors feedback-et jelölték meg pozitivumként. A kicsit szkeptikusok inkább az eredmények megbizhatóságát vonták kétségbe, vagyis nem biznak az eszközök pontosságában, aminek szintén lehet alapja.

Fontosnak tartja- e a testnevelő képzés technológiai irányú fejlesztését a jövőben?

38 válasz

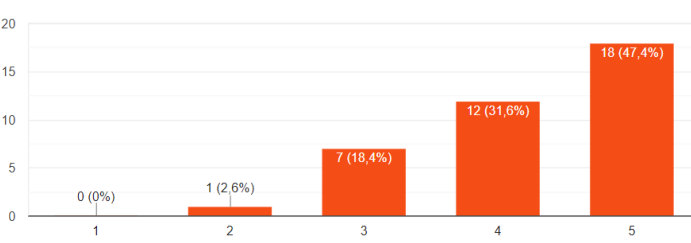

Fontosnak tartja- e a korszerú teljesítménymérō és analitikai eszközök, programok megismerését az egyetemi képzésben?

37 válas

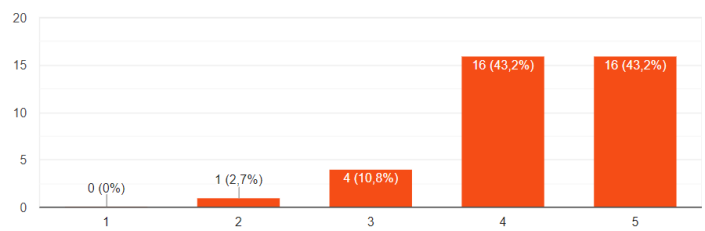


A képzés relevanciájára és tematikájára vonatkozó kérdések közül mindkettöre pozitivan reagáltak. A válaszadók mindkét esetben $70 \%$ felett nyilatkoztak a képzés technológiai megújitása és ezek megismerésének fontosságát illetően.

\section{A miniinterjú eredményei}

A mininterjúkérdései közül a két legérdekesebbet emelném ki, amelyek a digitális világ kihivásait boncolgatja.

1. Ön szerint milyen hatással van a technológiai fejlödés a korosztálya életére (proés kontra)?

A válaszok nagyon eltérőek voltak, és nem biztosak a technológia mindenhatóságában nagyon furcsának és ellentmondásosnak tartják azt a világot melyben élnek.

Volt, aki azt nyilatkozta a "tamagochi én magam vagyok" minden percét az elektronikus naptárja szerint éli szervezi. Volt, aki azt emelte ki, hogy a szük idöbeosztás mellet nagyon kedveli az elektronikusan elérhető tananyagokat, hiszen idöben és térben független lehet a tanteremtöl. Akadt olyan válasz is, aki a közösségi oldalalak szerepét emelte ki elsösorban azt, hogy példaképeit tudja követni és ez inspirálja őt is nagyobb teljesitményre.

2. Eddigi tanulmányaik során felkészitették-e Önöket az információs társadalom kihivásaira és megfelelő szintünek tartják-e ezt?

Az egyéni felkészültségük szintjérölaz információs társadalomban nem nyilatkoztak pozitivan, sokan érzik az eddigi felkészültségüket hiányosnak, nem ismernek igazán jó, megbizható információforrásokat, jellemzően gyors célirányos kérdésekre kevesen kapnak releváns választ, nem tanulták a keresési stratégiákat, kevés olyan alkalmazást ismernek, amely megkönnyiti az életüket. (Pl: Neptun rendszerröl órarend szinkronizálása mobilra.)

\section{Összegzés}

A kutatás eredményei bizonyítják, hogy érdemes a testnevelő képzésben az információ technológiai kérdésekkel foglalkozni, hiszen ezek az életük részei és mint kiderült, nagyon sok hallgatónak van mit pótolnia a kérdéskörben. Felmerül a kérdés ha bele tudjuk csempészni a mobiltechnológiát az iskolai testnevelés órákra is, lesz e motiváló hatása a mobil eszközök használatának az iskolai testnevelés órákon, illetve lesz- e ennek pozitiv következménye? Például egy virtuális Balaton körbefutás során, ahol csapatban mindenki digitális térképen megjelenitve tudja majd a saját teljesitményét a többiekkel megosztani. Ezek a kérdések még nyitottak mindenképpen megéri kipróbálni őket. 


\section{Irodalom}

[1] ARDUINI, BORGOGNI, CAPELLI (2016): The Portable Devices as Means to Promote Children's Active Lifestyle: The Case of a Walk To School Action in Italy in: Physical Education and new technologies (2016) szerk: Novak, Antala, Knjaz, Zagreb 2016. pp: 19-25. ISBN: 978-953-7965-05-1

[2] ARÉVALO, HERNANDO, MÓN, CATASÚS (2016): Physical Education And lct: An Unstoppable Combination in: Physical Education and new technologies (2016) szerk: Novak, Antala, Knjaz, Zagreb 2016. pp: 61-69. ISBN: 978-9537965-05-1

[3] KNJAZ, RUPČIĆ, ANTEKOLOVIĆ (2016): Application of Modern Technology in Teaching and Training with Special Emphasis on Basketball Contents in: Physical Education and new technologies (2016) szerk: Dario Novak, Branislav Antala, Damir Knjaz, Zagreb 2016. pp: 112-113 ISBN: 978-953-7965-05-1

[4] NETFIT koncepció: A 2015/2016. tanév NETFIT mérés eredményei tudományos elemzése

https://wWw.netfit.eu/public/pb_media.php?media=dokumentumok (2019. 09.07.)

[5] A viselhető eszközök trendjei: https://www.ericsson.com/4ge8cf/assets/ local/trends-and-insights/consumer-insights/consumerlab/infographs/ wearable-technology-infograph-ericsson-consumerlab-2016.pdf (2019. 09.07.)

[6] Sports Analytics Market - Global Industry Analysis, Size, Share, Growth, Trends and Forecast 2018 - 2026

https://www.transparencymarketresearch.com/sports-analytics-market. html (2019. 03.06) 